\title{
A Prospective Analysis of Antibodies Reacting with Pancreatic Islet Cells in Insulin-Dependent Diabetic Children
}

\author{
Å. Lernmark, B. Hägglöf, Z. Freedman, J. Irvine, J. Ludvigsson, and G. Holmgren \\ Hagedorn Research Laboratory, Gentofte, Denmark; Departments of Pediatrics, Universities of Umeå and Linköping, Sweden; \\ Department of Medicine, University of Chicago, Chicago, Illinois, USA; and The Endocrine Unit and Immunology Laboratories, \\ The Royal Infirmary, Edinburgh, Scotland
}

Summary. Islet cell cytoplasmic and cell surface antibodies along with other autogenic tissue antibodies were determined prospectively from the day of diagnosis of insulin-dependent diabetes in a group of children and adolescents. Prior to the initiation of insulin therapy 30 out of 33 were antibody-positive, $67 \%$ having islet cytoplasmic antibodies and $67 \%$ islet cell surface antibodies. Among 74 age- and sex-matched non-diabetic individuals $1 \%$ had islet cell cytoplasmic antibodies and 3\% had islet cell surface antibodies. A prospective analysis in 17 patients showed a diminishing prevalence of islet cell antibodies with increasing duration of diabetes. Islet cell cytoplasmic or cell surface antibodies were found independently of each other or in combination and with various patterns of persistence. The results indicate a strong association of islet cell antibodies with the onset of insulin-dependent diabetes in childhood and adolescence.

Key words: Insulin-dependent diabetes, islet cell antibodies, islet cell surface antobodies, autoimmunity.

In insulin-dependent diabetes mellitus (IDD) there is a high incidence of circulating antibodies which react with pancreatic islet cells $[1,2,3,4,5,6]$. Crosssectional analyses indicated that the prevalence of islet cell antibodies is maximal at the time of diagnosis of IDD $[1,3,5]$. In these studies islet cell antibodies were determined by an indirect immunofluorescence test on sections of frozen human pancreas. The assay requires the use of group 0 human pancreas and a positive reaction, primarily due to IgG [7], covers the cytoplasm of all the different endocrine cells in the islets $[7,8]$. However, serum from individuals with IDD also contains antibodies binding to the surface of dispersed islet cells [6]. Such antibodies were visualized in an indirect immunofluorescence test after incubation with serum from diabetic children [6]. Since living cells are impermeable to IgG the antigens in the two assay systems may not be the same. We have recently observed that islet cell cytoplasmic and surface antibodies may occur independently of each other in patients with IDD [9].

Little is known, however, about the prevalence and fate of islet cell antibodies determined by the different methods in IDD with onset before the age of twenty. In the present study we have determined prospectively from the onset of IDD both islet cell cytoplasmic and cell surface antibodies as well as other autoantibodies, in a group of children and adolescents.

\section{Materials and Methods}

\section{Patients}

Serum or plasma was collected from 33 insulin-dependent diabetics, 1-16 years of age, admitted to the Departments of Paediatrics at the University Hospitals of Umeå or Linköbing (Table 1). In all patients blood was drawn on the day of diagnosis before the start of insulin therapy. In 17 of the patients blood samples were obtained at routine clinical visits 1, 3, 6 and 9 months later.

\section{Controls}

Serum or plasma was obtained from 74 non-diabetic school children, 4-20 years of age (Table 1) from Umeå, Sweden. None had a family history of IDD among first-degree relatives. Informed consent was obtained from all the diabetic and non-diabetic individuals and their parents.

\section{Islet Cell Cytoplasmic Antibodies}

Plasma or serum samples were stored at $-20^{\circ} \mathrm{C}$ before use in an indirect, immunofluorescent assay [8], with undiluted samples applied to fresh, snap-frozen pancreatic tissue of a donor with 
Table 1. Islet cell and other tissue antibodies in healthy and insulin-dependent diabetic children at the day of diagnosis

\begin{tabular}{lll}
\hline & $\begin{array}{l}\text { Healthy } \\
\text { subjects }\end{array}$ & $\begin{array}{l}\text { Insulin- } \\
\text { dependent } \\
\text { diabetics }\end{array}$ \\
\hline $\begin{array}{l}\text { No. of subjects } \\
\begin{array}{l}\text { Age (years) } \\
\quad \text { Mean }\end{array}\end{array}$ & 74 & 33 \\
$\quad$ Range & 13 & 9 \\
Female/male ratio & $4-20$ & $1-16$ \\
$\begin{array}{l}\text { Islet cell antibodies } \\
\quad \text { Cytoplasmic } \\
\text { (frozen pancreas sections) }\end{array}$ & $36 / 38$ & $14 / 19$ \\
$\quad \begin{array}{l}\text { Surface } \\
\text { (living mouse B-cells) }\end{array}$ & 1 & \\
$\quad$ Cytoplasmic and/or surface & 2 & 22 \\
$\begin{array}{l}\text { Antibodies against } \\
\text { thyroid cells } \\
\text { gastric-parietal cells }\end{array}$ & 3 & 22 \\
$\begin{array}{l}\text { smooth muscle } \\
\text { reticulin } \\
\text { mitochondria }\end{array}$ & 3 & 30 \\
\hline
\end{tabular}

blood group 0 and fluorescein-isothiocyanate-conjugated rabbit anti-human IgG (Wellcome Laboratories, Buckinghamshire, $\mathrm{UK}$ ). The results were read by two independent readers with a Leitz Orthoplan Microscope fitted with a mercury vapour lamp and Ploem illuminator with $\mathrm{KGq}, \mathrm{BG} 38, \mathrm{KP} 490 / \mathrm{X} 2$, GT 475 , TK 510 dichroic mirrors and K 515-filters.

\section{Islet Cell Surface Antibodies}

Plasma or serum was heat-inactivated $\left(56^{\circ} \mathrm{C}, 20 \mathrm{~min}\right)$ and subjected to ammonium sulphate precipitation at $33 \%$ saturation. After incubation for $60 \mathrm{~min}$ at $4{ }^{\circ} \mathrm{C}$ with slow rotation of the tubes, the precipitate was collected at $4^{\circ} \mathrm{C}$ by centrifugation at $2200 \mathrm{x} \mathrm{g}$, and dissolved in the original sample volume in a $10 \mathrm{mmol} / 1$ Hepes (N-hydroxyethyl piperazine-N-2-ethane-sulfonic acid) buffer, $\mathrm{pH}$ 7.4 , containing $140 \mathrm{mmol} / \mathrm{l} \mathrm{NaCl}$. The resulting solution was dialyzed against 100 to 200 volumes of the same buffer for $24 \mathrm{~h}$ at $4^{\circ} \mathrm{C}$ and finally centrifuged at $100000 \mathrm{x}$ g for $60 \mathrm{~min}$. The supernatant fluid was stored in aliquots at $-20^{\circ} \mathrm{C}$.

Pancreatic islets were prepared from Sprague-Dawley rats or $o b / o b$ mice as described in detail elsewhere $(6,10,11)$. The pancreatic islets were dispersed into cell suspensions by mechanical shaking in Swim's S-77 medium (Grand Island Biological Company, New York, USA) containing ethylene-glycol-bis (oxyethylenenitrilo)tetra-acetic acid (EGTA). The dispersed cells were incubated with the serum preparations as described in detail elsewhere [6]. Antibodies binding to the surface of the cells were revealed in an indirect, immunofluorescence test with fluoresceinisothiocyanate conjugated rabbit anti-human IgG (Miles Laboratories, Elkhart, Indiana or DAKO Immunoglobulins, Copenhagen, Denmark). The cells were mounted live on coded slides. The serum samples were run at random and were evaluated independently by two investigators in Umeå and by one in Chicago using a phase contrast microscope equipped with a Zeiss IV FI epifluorescence condenser. A minimum of 100 single and intact cells, as judged by phase-contrast microscopy, were evaluated for the presence of a cell surface immunofluorescence reaction in a $1: 1$ dilution of fractioned serum.

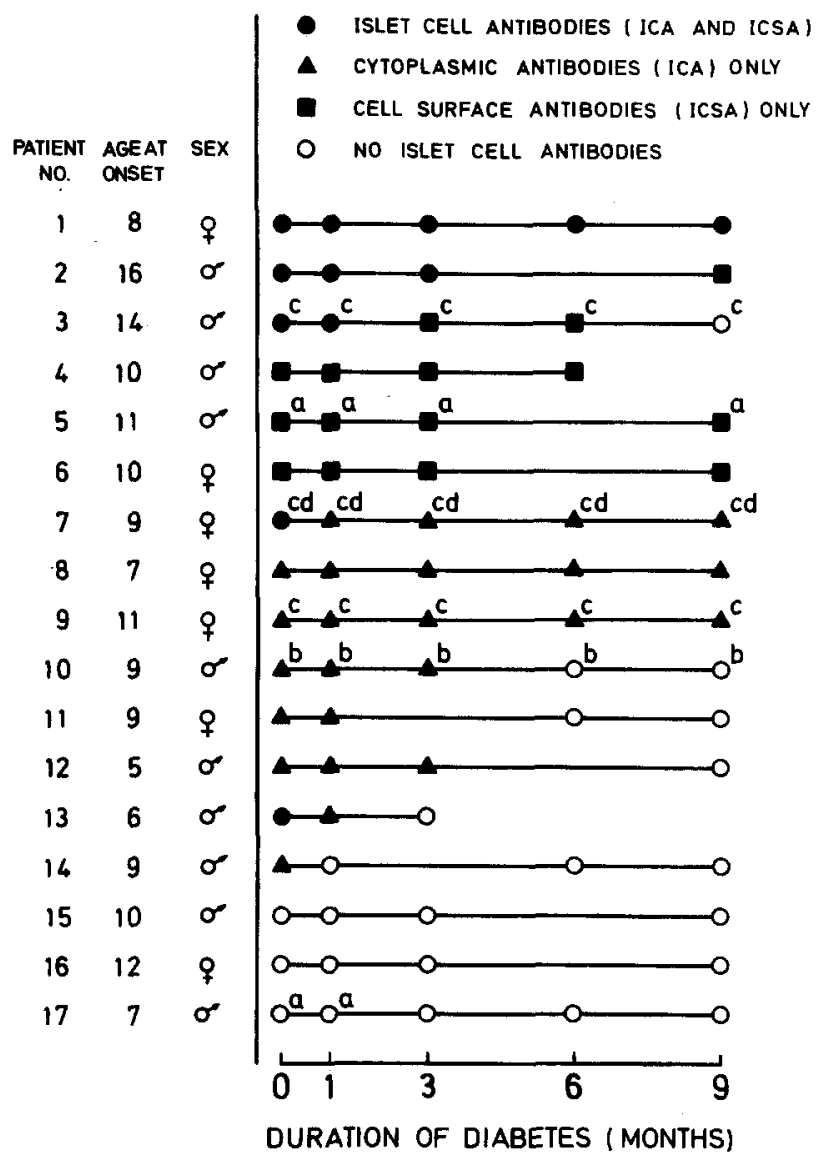

Fig. 1. Prospective analysis of islet cell antibodies in 17 insulindependent diabetic children and adolescents. Cytoplasmic islet cell antibodies (ICA) were determined by an indirect immunofluorescence test on sections of frozen human pancreas. Surface islet cell antibodies (ICSA) were determined in an indirect immunofluorescence test on suspensions of live ob/ob mouse and rat islet cells. Other autogenic antibodies: ${ }^{\mathrm{a}}$ smooth muscle cell antibodies, ${ }^{b}$ gastric parietal cell antibodies, ${ }^{c}$ anti-nuclear antibodies (the fluorescence analysis was carried out at a sample dilution not diagnostic for anti-nuclear factor), ${ }^{d}$ thyroid cell antibodies

The analyses on rat and ob/ob mouse islet cells were carried out independently on coded samples at separate laboratories. Out of 155 samples from diabetic and healthy children $85 \%$ of the samples were scored the same, positive or negative, when tested on either mouse or rat islet cells. Only samples scored as antibody positive in both tests were entered as an antibody-positive sample in the final statistical analysis.

In a group of 16 children sufficient serum was available from the day of diagnosis to determine islet cell cytoplasmic and cell surface antibodies on ob/ob mouse islet cells only.

\section{Other Tissue Antibodies}

Antibodies to thyroid cytoplasm, gastric parietal cells, smooth muscle, mitochondria, reticulin, as well as anti-nuclear factor were assessed by indirect immunofluorescence test using frozen sections of human thyroid, rat stomach, rat liver or rat kidney. The results were read as in the islet cell cytoplasmic antibody test. 
Table 2. Islet cell antibodies in insulin-dependent diabetic children in relation to the duration of the disease

\begin{tabular}{lcccccc}
\hline Islet cell antibodies & \multicolumn{2}{l}{ Duration of diabetes (months) } & & & \\
\cline { 2 - 6 } & At admission & 1 & 3 & 6 & 9 & 18 \\
\hline Cytoplasmic & $11 / 17$ & $10 / 17$ & $7 / 15$ & $3 / 11$ & $4 / 15$ & $1 / 4$ \\
Cell surface & & & & & \\
ob/ob mouse islet cells & $11 / 17$ & $10 / 16$ & $9 / 13$ & $4 / 8$ & $7 / 16$ & $2 / 5$ \\
Rat islet cells & $9 / 17$ & $6 / 15$ & $4 / 13$ & $3 / 10$ & $4 / 16$ & $1 / 5$ \\
\hline
\end{tabular}

\section{Results}

Prior to the start of insulin therapy $91 \%$ of serum samples obtained from insulin-dependent diabetics were positive in the immunofluorescence tests for islet cell antibodies (Table 1). The proportion of discordant scores between islet cell cytoplasmic or surface antibodies was $49 \%$ (16 out of 33 patients analyzed). Thus, $67 \%$ of the patients were antibodypositive using sections of frozen human pancreas and $67 \%$ with suspensions of living ob/ob mouse B-cells.

Only $4 \%$ of the sera from 74 non-diabetic individuals were islet antibody-positive with a low frequency of antibodies against other cells or cellular constituents (Table 1). None of the individuals with anti-thyroid or anti-gastric-parietal cell antibodies had islet cell antibodies. Two out of the three nondiabetics with smooth muscle antibodies also had detectable islet cell surface antibodies. The frequency of various tissue antibodies among insulin-dependent diabetic children was similar to that of the healthy controls.

In 17 children and adolescents followed prospectively from the day of diagnosis over 9 months of diabetes, $14(82 \%)$ had islet cell antibodies prior to the start of insulin therapy (Fig. 1). Eight of the 14 antibody-positive patients $(57 \%)$ remained positive when followed for 6 ( 1 patient) to 9 ( 7 patients) months. The results in Figure 1 demonstrate that cytoplasmic and cell surface antibodies may be present independently of each other and that the pattern of persistence of one or both is very variable.

Other tissue antibodies were present in six patient sera (Fig. 1). In all but one sample the tissue antibodies remained positive throughout the nine-month period. In one patient (No. 10) gastric-parietal cell antibodies were present throughout the nine-month period, while sera remained positive for islet cell cytoplasmic antibodies for only three months.

The prevalence of islet cell antibodies determined in the three different assay systems diminished with increasing duration of diabetes (Table 2). Out of 16 patients $4(25 \%)$ had cytoplasmic and 4-7 (25-44\%) cell surface antibodies after 9 months of diabetes. The prevalence decreased to 1-2 antibody-positive patients out of $4-5$ after 18 months.

\section{Discussion}

Our results provide evidence that there is a strong association of islet cell antibodies with the onset of insulin-dependent diabetes in childhood and adolescence. In all patients, representing about $70 \%$ of those IDD-patients diagnosed during one year at two Swedish paediatric clinics, care was taken to obtain a serum sample before the insulin treatment was initiated. While the assay of islet cell antibodies using sections of human pancreas confirms previous observations in young IDD patients with sera obtained at, or close to, diagnosis $[1,3,5]$, the simultaneous determination of islet cell surface antibodies increased the frequency of antibody-positive sera from $67 \%$ of either surface or cytoplasmic alone to more than $90 \%$. In a previous investigation with a mixed group of young and adult IDD-patients [9] with disease duration of less than one month, the use of both methods for antibody-detection increased the number of patients with an immunological marker of the disease from $41-68 \%$ to $80 \%$.

When islet cell surface antibodies were analysed by cell surface immunoflourescence on rat or ob/ob mouse islet cells, comparable results were obtained. The assay on ob/ob mouse islet cells tended to give a higher frequency of antibody positive sera (Fig. 2). This may be due to species differences or to the composition of endocrine cells, being $75-80 \%$ B-cells in the rat but more than $90 \%$ in ob/ob mouse $[10,12$, 13]. Since positive sera tend to react with $40-75 \%$ of the cells observed in a given sample [6] it was concluded that the islet cell surface antibodies were directed towards B-cells. However, this does not exclude the possibility that antibodies reactive with other endocrine islet cell types are present as well.

The data in Table 1 and Figure 1 suggest that islet cell antibodies may be tissue specific since there was no correlation with other tissue antibodies. In addi- 
tion, sera positive to living rat islet cells were little affected by pre-absorption to rat hepatocytes or erythrocytes, or to various rat tissues [6]. Prospective analyses of islet cell antibodies and other tissue antibodies (Fig. 1) suggested that the antibodies may appear and disappear independently of one another. In accordance with previous reports $[2,3,4,5]$ islet cell antibodies were evanescent. Thus, within 9 months of diagnosis they disappeared in 6 out of 13 $(46 \%)$ patients who were positive on the day of diagnosis (Fig. 1). In one individual, smooth muscle cell antibodies were also temporarily present, whilst other tissue antibodies did not disappear. There is no obvious explanation of why the prevalence of islet cell antibodies depends on the duration of the diabetic condition.

The role of islet cell antibodies in the pathogenesis of IDD is unclear. We conclude from the present investigation that islet cell antibodies at the time of diagnosis of IDD are heterogenous, which may signify the presence of antibodies against different antigens.

Acknowledgements. This study was supported in part by the Swedish Diabetes Association and grants AM 26190 and AM 20595 from the National Institutes of Health and Vera and Carl Johan Michaelsens Legat. Determinations of islet cell surface antibodies on ob/ob mouse islet cells were carried out at the Department of Histology, University of Umeå, Umeå, Sweden with expert technical assistance by Miss Gunilla Forsgren.

\section{References}

1. Lendrum R, Walker G, Gamble DR (1975) Islet-cell antibodies in juvenile diabetes mellitus of recent onset. Lancet I: 880-883

2. Lendrum R, Walker G, Cudworth AG, Theophanides C, Pyke DA, Bloom A, Gamble DR (1976) Islet-cell antibodies in diabetes mellitus. Lancet II: 1273-1276
3. Irvine WJ, McCallum CJ, Gray RS, Campbell GJ, Duncan LJP, Farquhar JW, Vaughan H, Morris PJ (1977) Pancreatic islet cell antibodies in diabetes mellitus correlated with the duration and type of diabetes, coexistent autoimmune disease, and HLA-type. Diabetes 26: 138-147

4. Del Prete GF, Tiengo A, Bersani G, Nosadini R, Garotti C, Trisotto A (1976) Insulin and glucagon response to glucose and arginine in two patients with "autoimmune" diabetes mellitus. Horm Metab Res 8: 149-150

5. Botazzo GF, Mann JI, Thorogood M, Baum JD, Doniach D (1978) Autoimmunity in juvenile diabetics and their families. Br Med J II: $165-168$

6. Lernmark A, Freedman ZR, Hofmann C, Rubenstein AH, Steiner DF, Jackson RL, Winter RJ, Traisman HS (1978a) Islet cell surface antibodies in juvenile diabetes mellitus. Engl J Med 299: 375-380

7. Botazzo GF, Florin-Christensen A, Doniach D (1974) Islet cell antibodies in diabetes mellitus with autoimmune polyendocrine deficiencies. Lancet II: 1279-1283

8. MacCuish AC, Jordan J, Campbell CJ, Duncan LJP, Irvine WJ (1974) Antibodies to islet-cells in insulin-dependent diabetics with coexistent autoimmune disease. Lancet II: 1529-1533

9. Freedman ZR, Feek CM, Irvine WJ, Lernmark $\AA$, Rubenstein AH, Steiner DF, Huen A (1979) Islet cell cytoplasmic and cell surface antibodies in diabetes mellitus. Trans Assoc Am Physicians 96: 64-76

10. Lernmark $\AA$ (1974) The preparation of, and studies on, free cell suspension from mouse pancreatic islets. Diabetologia 10: $431-438$

11. Lernmark A, Nathans A, Steiner DF (1976) Preparation and characterization of plasma membrane-enriched fractions from rat pancreatic islets. J Cell Biol 71: 606-623

12. Hellman B (1959) The total volume of the pancreatic tissue at different ages in the rat. Acta Pathol Microbiol Scand 47: $35-42$

13. Hellman B (1965) Studies in obese-hyperglycemic mice. Ann NY Acad Sci 131: 541-558

Received: May 16, 1980,

and in revised form: November 11, 1980

Åke Lernmark, M. D.

Hagedorn Research Laboratory

Niels Steensensvej 6

DK-2820 Gentofte

Denmark 